\title{
Literacy on Crop Insurance of the Farmers in Licab, Nueva Ecija, Philippines
}

\author{
Alvin Gino M. Bautista, MBA, LPT
}

College of Management and Business Technology, Nueva Ecija University of Science and Technology, Cabanatuan City, Philippines

\begin{abstract}
Farming is a game of chance, and because we do not know what will happen tomorrow, we never knew when the calamities will occur. On the brighter side, the Philippine government has its agency that will protect and will ease the problem of many farmers by getting crop insurance, this is the Philippine Crop Insurance Corporation.

This study focused primarily on the literacy on crop insurance of the farmers in Licab, Nueva Ecija. The descriptive method of research was used which involved description, interview, recording, analysis, and interpretation of condition that presently exist in one hundred (100) respondents from different barangay of Licab, Nueva Ecija who answered the interview and questionnaires given by the researcher.

After all the pertinent data was collected, the researcher discovered and conclude that only $43 \%$ of the respondents have an idea about crop insurance and some of this figure were policyholders. One of the reasons why they do not get the service of PCIC is because, although they want to have it, they do not have enough budget for it and they need more information for them to be literate about this type of insurance. The researcher recommends having seminars for information dissemination to boost the literacy of the farmers in the area and to increase the policyholders of Philippine Crop Insurance Corporation.
\end{abstract}

Keywords-Crop Insurance, Farmers;Licab, Nueva Ecija, Agricultural Risks.

\section{INTRODUCTION}

Agriculture is very much vulnerable to the unpredictability of nature. With agricultural production representing the major livelihood of many resources constrained Filipino farmers, the impact of natural disasters and agricultural risks cannot be taken lightly. Other agribusinesses and commercial farms that operate with higher capital and better technology on better lands are also not spared from the same risks. The need to safeguard the interest and investments of local farmers and industry players is therefore of paramount importance. (Estacio and Modeno 2001)

Crop insurance is purchased by agricultural producers, including farmers, ranchers, and others to protect against either the loss of their crops due to fortuitus events or natural disasters, or the loss of revenue due to declines in the prices of agricultural commodities. Crop insurance covers crop losses, including lower yields, caused by natural events, such as Destructive weather, Disease, Drought, Fire, Flooding, and Insect Damage. (Insurance Information Institute)

The researcher assumes that most of the farmers especially in Licab, Nueva Ecija. Know that the government under the Department of Agriculture has a program about crop insurance, on the other hand, why many of them were not interested in the said program? Farmers always plan and give the right ways on how to take care of their crops to get a better harvest at the end of the season. But most of the time, there are lots of unwanted calamities and pests that ruined their yield and will give them bad results. That is why crop insurance is very important nowadays.

This study will focus on the literacy on crop insurance of the farmers in Licab, Nueva Ecija wherein 
approximately $10 \%$ to $20 \%$ only of the farmers have been and currently a member of different crop insurance policies.

\section{OBJECTIVES OF THESTUDY}

The main objective of this study will be assessing the literacy of the respondents in the municipality of Licab, Nueva Ecija on Crop Insurance. This study specifically aims to answer the following problems:

1. How well the respondents know about crop insurance?

2. What are the common problems the respondents encounter in understanding the crop insurance?

3. How many have been invested in crop insurance in the locale?

4. How many are interested in crop insurance?

5. Is gender and the respondents' literacy about crop insurance has a significant difference?

This research will be beneficial to the farmers in the area, for they will understand the crop insurance, its package suitable to their farm, its benefits, and it will widen their connections with regards to farmers' cooperatives, agricultural lenders, and service providers. It will also be beneficial to the Philippine Crop Insurance Corporation (PCIC) wherein they can promote their company and their products to the farmers of Licab.

Lastly, the objective of this study is to identify the problems that the respondents encounter in understanding crop insurance.

\section{METHODOLOGY}

The study will be dealing with the present status of the literacy of the respondents concerning investing in crop insurance in Licab, Nueva Ecija. Licab, Nueva Ecija is a fourth-class municipality in the province of Nueva Ecija, Philippines, that has 11 barangays. A descriptive method of research was used in this study because it is the most appropriate research design that will match to the interviews and questionnaires for selected 100 respondents.

The survey was created using a suitable question modified from related research and individual questions which was formed by the researcher. The researcher utilized the mean, median, mode, frequency, and percentage for the description of the respondents in terms of their age, sex, educational attainment, and farm size. For the assessment of the relationship between sex, and the respondents' literacy about crop insurance, the researcher used Chi-Square Test $\left(\mathrm{X}^{2}\right)$ to describe the relationship between the variables.

\section{RESULTS AND DISCUSSION}

The result of the survey conducted by the researcher with 100 farmers in Licab, Nueva Ecija is presented below:

\subsection{Profile of the Respondents}

Table 1. Sex of the Respondents

\begin{tabular}{|c|c|c|}
\hline Sex & Frequency & Percentage \\
\hline Male & 75 & $75 \%$ \\
\hline Female & 25 & $25 \%$ \\
\hline Total & 100 & $100 \%$ \\
\hline
\end{tabular}

Table 1 represents 100 respondents wherein $75 \%$ or the majority were Male and 25\% representing the minority were Female. Most of these female respondents are farm owners and not working directly on the farm, they get the service of another farmer who will be the caretaker who is a male that gets the $10 \%$ of the gross harvest of the latter.

Table 2. Age of the Respondents

\begin{tabular}{|c|c|c|}
\hline Age & Frequency & Percentage \\
\hline $20-30$ & 16 & $16 \%$ \\
\hline $31-40$ & 26 & $26 \%$ \\
\hline $41-50$ & 31 & $31 \%$ \\
\hline $51-60$ & 22 & $22 \%$ \\
\hline 60 and above & 5 & $5 \%$ \\
\hline Total & 100 & $100 \%$ \\
\hline
\end{tabular}

Table 2 shows that the Mode of the respondents belongs to the bracket 41-50. Some of these farmers got their land from their family who has the same manner of business, others bought it from other farmers. The reason why most of the farmers belong to this age bracket is that they have the capacity to buy new farm land, they are people who have enough savings that can be used to buy for investments purpose. 
Table 3. Educational Attainment

\begin{tabular}{|c|c|c|}
\hline Educational Attainment & $\begin{array}{c}\text { Frequenc } \\
\mathbf{y}\end{array}$ & Percentage \\
\hline Primary - Not Completed & 12 & $12 \%$ \\
\hline Primary - Completed & 16 & $16 \%$ \\
\hline Secondary -Not Completed & 20 & $20 \%$ \\
\hline Secondary - Completed & 35 & $35 \%$ \\
\hline Tertiary - Not Completed & 10 & $10 \%$ \\
\hline Tertiary - Completed & 7 & $7 \%$ \\
\hline Total & 100 & $100 \%$ \\
\hline
\end{tabular}

Based on the result of the survey shown in Table 3, most of the respondents were Completed their Secondary level. Many of them did not continue for the tertiary level for different reasons and they opt to stay in the farming field. The study proved that many of the farmers have no concrete education or bachelor's degree. On the contrary, farming doesn't need further education unless you are mastering the art and science of farming.

Table 4. Size of the Farm

\begin{tabular}{|c|c|c|}
\hline Size of Farm & Frequency & Percentage \\
\hline Below 1 hectare & 30 & $30 \%$ \\
\hline 1.1 to 2 Hectares & 22 & $22 \%$ \\
\hline 2.1 to 3 Hectares & 12 & $12 \%$ \\
\hline 3.1 to 4 Hectares & 15 & $15 \%$ \\
\hline 4.1 to 5 Hectares & 8 & $8 \%$ \\
\hline 5.1 to 6 Hectares & 8 & $8 \%$ \\
\hline 6.1 to 7 Hectares & 3 & $3 \%$ \\
\hline 7.1 and above & 2 & $2 \%$ \\
\hline Total & 100 & $100 \%$ \\
\hline
\end{tabular}

As shown in Table 4, the farm size of the respondents is mostly 1 hectare and below, it represents $30 \%$ of the total respondent, they are known as the small-scale farmers. They are the farmers who have small incomes compare to others who have higher farm sizes than them.
Table 5. Crop Insurance Literacy

\begin{tabular}{|c|c|c|}
\hline $\begin{array}{c}\text { How well do you know } \\
\text { Crop Insurance }\end{array}$ & $\begin{array}{c}\text { Frequenc } \\
\mathbf{y}\end{array}$ & Percentage \\
\hline Very Well & 30 & $30 \%$ \\
\hline Minimal Idea & 43 & $43 \%$ \\
\hline No Idea & 27 & $27 \%$ \\
\hline Total & 100 & $100 \%$ \\
\hline
\end{tabular}

Concerning the literacy of the farmers about crop insurance, $27 \%$ of the respondents have No Idea about it. One of the respondents said that he is not interested even though the government has this program for the benefits of the farmers like him. This kind of farmers needs a lot of encouragement and seminars that will enlighten them to be part of said insurance. On the other hand, as $43 \%$ of the total respondents have a Minimal Idea, and the remaining 30\% are having adequate information about the subject matter, but some of this figure were not a current policyholder.Its simple shows that it does not mean you knew everything about crop insurance, you will buy a policy.

Table 6. Number of Policy Holders

\begin{tabular}{|c|c|c|}
\hline $\begin{array}{c}\text { Are you a } \\
\text { policyholder of } \\
\text { Crop Insurance? }\end{array}$ & Frequency & Percentage \\
\hline Yes & 22 & $22 \%$ \\
\hline No & 78 & $78 \%$ \\
\hline Total & 100 & $100 \%$ \\
\hline
\end{tabular}

Table 6 shows that among the 100 respondents, only $22 \%$ are crop insurance policyholders and the majority are not members for different reasons like: out of farming budget, lack of information about it, unqualified farm owner due to the flooded area, and so on.

Table 7. Reason for not availing Crop Insurance

\begin{tabular}{|c|c|c|}
\hline $\begin{array}{c}\text { Reason for not availing crop } \\
\text { insurance }\end{array}$ & Frequency & Percentage \\
\hline Not part of farming budget & 34 & $44 \%$ \\
\hline I have an idea but don't know-how & 26 & $33 \%$ \\
\hline Lack of Idea & 11 & $14 \%$ \\
\hline
\end{tabular}




\begin{tabular}{|c|c|c|}
\hline Others & 7 & $9 \%$ \\
\hline Total & 78 & $100 \%$ \\
\hline
\end{tabular}

Based on the previous Table 6, it is shown in Table 7 that there were $78 \%$ of the respondents were not a policyholder, thus, it is noted that the main problem of the farmers is, it is not part of their farming budget. Many of the farmers were belongs to the poverty level of the society that is why instead of putting their money into insurance they will use it for much essential matter for their everyday living.

\section{CONCLUSION AND RECOMMENDATIONS}

After a thorough gathering of data on the descriptive investigation, the researcher made an analysis of the literacy on crop insurance of farmers in Licab, Nueva Ecija and the researcher arrived at the following conclusions and recommendations: that there is no significant relationship between the respondents' gender and their crop insurance literacy using Chi-Square Test $\left(\mathrm{X}^{2}\right)$.

Furthermore, crop insurance is not easy to sell especially to those farmers who have insufficient and sometimes less income than usual, on the other hand, if the government wants to succeed with regards to this matter, they need to enhance their method on reaching the literacy of every farmer through further seminars and continues discussions with the farmers to let them know that crop insurance is really for their benefits.

Strong partnership with private sectors and cooperative is advised to acquire assistance in the promotion of crop insurance in the municipality of Licab. To encourage more members, PCIC should lessen the payment for the first three cropping seasons upon subscribing to the policyholder. Pamphlets and other reading materials about crop insurance must be given to the farmers so that they can read and answer those questions on their minds. It can also give them information and ideas that are very useful in understanding the said insurance. PCIC should give the quality of its services especially in times of reimbursement of claims. If the service is good from the start until the end, people will not discontinue their subscriptions and can encourage others to become a member and policyholders. The adjuster should be independent and must base his judgment on the truth.

The government should enlarge their policy about crop insurance so that other farms which are prone to calamities can be qualified. Farmers, on the other hand, should study how are the right ways on farm budgeting through seminars. It can help them to minimize their expenses without compromising their produces. Lastly, crop insurance is highly recommendable to all qualified farmers. They must consider it as one of the best risk management tools that can help them for the betterment of their lives. If the government, private sectors, farmers and other stakeholders will join together to boost the literacy of all farmers about crop insurance, and the benefits of getting it, losses in farming will be eliminated.

\section{REFERENCES}

[1] Reyes, Celia M. and Domingo, Sonny N. Crop Insurance in the Philippines: Security for the Farmers and Agricultural Stakeholder, Discussion Paper Series No. 2009-12

[2] Dean Karlan et al, Examining the effects of Crop Price Insurance for Farmers in Ghana, 2009

[3] Wang Ming, et al, Are People Willing to Buy Natural Disaster Insurance in China? Risk Awareness, Insurance Acceptance, and Willingness to Pay, 2012

[4] Brent A. Gloy and A.E Staehr, Case Study on the Use of Crop Insurance in Managing Risk, Cornell University, Ithaca N.Y, 2009

[5] Insurance of Crop in Developing Countries by Food and Agriculture Organization of United Nation, 2005

[6] Daniel Clarke and Stefan Dercon, Insurance, Credit and Safety Nets for the Poor in a World of Risk, October 2009

[7] Insurance Information Institute, Understanding Crop Insurance, https://www.iii.org/article/ understanding-cropinsurance

[8] Estacio $\mathrm{BF}$ and Mordeno NB, Crop Insurance in the Philippines: Security for Farmers and Agricultural Stakeholders, 2001 